\title{
Pleasing Fungus Beetles, Pseudischyrus, Tritoma, Megalodacne, Ischyrus spp. (Insecta: Coleoptera: Erotylidae) $)^{1}$
}

Paul E. Skelley ${ }^{2}$

\section{Introduction}

The bright color patterns of pleasing fungus beetles never fail to attract attention, but because of their cryptic habits they are rarely seen except by the dedicated mushroom hunter and entomologists.

\section{Taxonomy}

The family Erotylidae has been thoroughly revised by Boyle (1956) for America north of Mexico. Since then nothing has been published to change the taxonomic standing of the species in the United States. Much taxonomic work, however, remains to be done before the tropical fauna is as well known.

\section{Distribution}

Pleasing fungus beetles are worldwide in distribution, but the vast majority of the species occur in the tropics. Of the approximately 1,800 known species, only 51 are found in America north of
Mexico; 18 species have been recorded from or are known to occur in Florida (Skelley 1988).

\section{Description}

Most pleasing fungus beetles are easily recognized by their reddish-orange and black color pattern, although there are a few exceptions. Members of the genus Pseudischyrus and some of Tritoma are entirely brown or black. Most species in the southeastern United States are black with a red head and prothorax, but a few are more elaborately patterned. Because many other beetles share this black and red color pattern, additional characters are needed for identification.

Important structural characters include their clubbed antenna, 5-5-5 tarsal formula, usually dilated maxillary palps, and lack of pubescence. Pleasing fungus beetles range in size from 2.0 to $3.5 \mathrm{~mm}$ long in Dacne to 14.0 to $22.0 \mathrm{~mm}$ long in Megalodacne. Most Florida species are less than $10 \mathrm{~mm}$ in length. Body shape usually is elongate-oval or egg-shaped.

1. This document is EENY-091 (originally published as DPI Entomology Circular No. 313), one of a series of Featured Creatures from the Entomology and Nematology Department, Florida Cooperative Extension Service, Institute of Food and Agricultural Sciences, University of Florida. Published: June 1999. This document is also available on Featured Creatures Website at http://creatures.ifas.ufl.edu. Please visit the EDIS Website at http://edis.ifas.ufl.edu. Additional information on these organisms, including many color photographs, is available at the Entomology and Nematology Department WWW site at http://entnemdept.ifas.ufl.edu/.

2. Paul E. Skelley, Florida Department of Agriculture and Consumer Services, Division of Plant Industry, Gainesville, FL.

The Institute of Food and Agricultural Sciences (IFAS) is an Equal Employment Opportunity - Affirmative Action Employer authorized to provide research, educational information and other services only to individuals and institutions that function without regard to race, creed, color, religion, age, disability, sex, sexual orientation, marital status, national origin, political opinions or affiliations. For information on obtaining other extension publications, contact your county Cooperative Extension Service office. Florida Cooperative Extension Service / Institute of Food and Agricultural Sciences / University of Florida / Larry R. Arrington, Interim Dean 

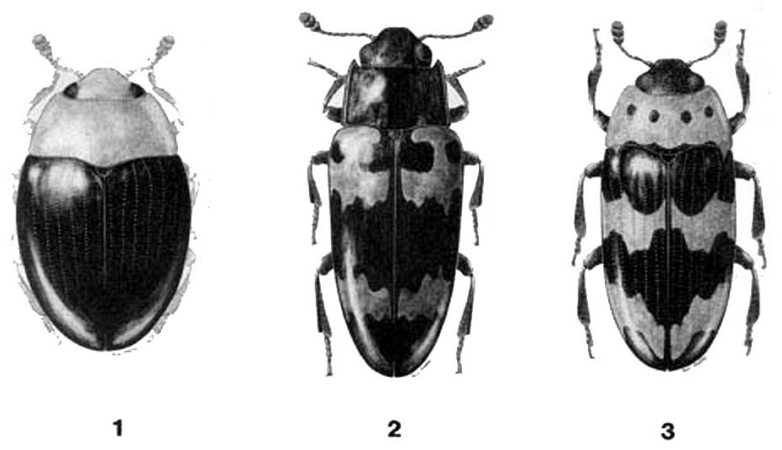

Figure 1. 1) Tritoma atriventis LeConte - $2.0 \mathrm{~mm}$; 2) Megalodacne heros (Say) - $8.0 \mathrm{~mm}$; 3) Ischyrus $q$. quadripunctatus (Olivier) - $4.0 \mathrm{~mm}$ Credits: Paul M. Choate, University of Florida

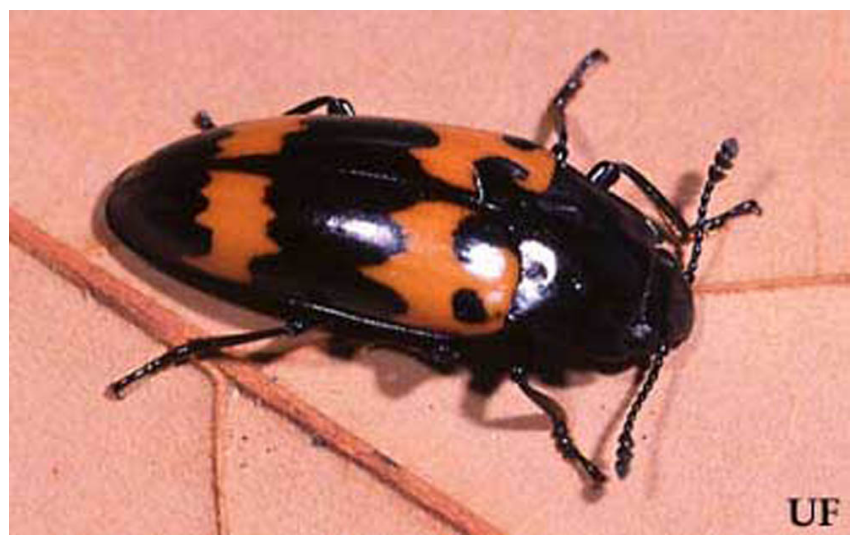

Figure 2. Adult pleasing fungus beetle, Megalodacne spp. Credits: Paul M. Choate, University of Florida

Useful references for identifying these beetles are Boyle (1956) and Dillon and Dillon (1961).

\section{Biology}

Pleasing fungus beetles feed on the fruiting bodies of fungi. A wide variety of fungi serves as hosts for the family as a whole, but each pleasing fungus beetle species seems to be specific to a certain group of fungi. The species with larger individuals, such as Megalodacne spp., feed in the harder bracket fungi (Ganoderma spp.) found on dead trees and stumps. Common Triplax spp. feed on oyster mushrooms (Pleurotus spp.) which grow on dead logs. Tritoma spp. feed on mushrooms growing from dead roots and logs, while members of Pseudischyrus and other Tritoma spp. feed on fungi that have mycorrhyzal associations with living tree roots. These mushrooms include brittlegill mushrooms (Russula spp.) and deathcap mushrooms (Amanita spp.).
McKnight and McKnight (1987) is useful in mushroom recognition.

As with most insects that depend on ephemeral food sources, the larval stage generally passes quickly: two weeks from egg to pupa is not uncommon. The sluggish larvae are only found associated with the mature host fruiting body. Adults are often found on the host fungus in large numbers with the larvae. However, adults are also found away from the host. When conditions are unfavorable for the host fungi to fruit, adults often congregate under bark or in other hiding places. The causal factors and mechanisms which lead to these aggregations are unknown.

\section{Economic Importance}

In the United States, the pleasing fungus beetles are not economically important, but in the Orient where many people regularly collect and eat wild mushrooms, pleasing fungus beetles may be considered pests (Boyle 1956). Many of the fungi upon which these beetles feed are edible by humans. Currently none of these fungi is easily cultivated and they are not sought after by most people. With the increasing popularity of mushrooms and cultural technological advances, it is possible that pleasing fungus beetles may become economically important in the United States. If these beetles become pests, chemical control is not recommended because mushrooms are very absorbent. Biological or cultural controls should be considered.

These beetles may also be beneficial. Fungi like Inonotus spp. and Armillariella spp. are known to be pathogenic to hardwood trees. These fungi also serve as hosts for several species of pleasing fungus beetles.

\section{Selected References}

Boyle, W.W. 1956. A revision of the Erotylidae of America north of Mexico (Coleoptera). Bulletin of the American Museum of Natural History 110: 61-172.

Dillon, E.S. and L.S. Dillon. 1961. A Manual of Common Beetles of Eastern North America. Row, Peterson and Company, Evanston, IL. 884 p. 
McKnight, K.H. and V.B. McKnight. 1987.

Peterson Field Guide to Mushrooms. Houghton

Mifflin Company, Boston. 429 p.

Skelley, P. 1988. The pleasing fungus beetles of

Florida (Coleoptera: Erotylidae). M.S. thesis.

University of Florida, Central Science Library.

Gainesville, FL. 172 pp. 